\title{
REVIEW
}

\section{Cell population characterization and discovery using single-cell technologies in endocrine systems}

\author{
Leonard Y M Cheung(i)1 and Karine Rizzoti(1)2 \\ 'Department of Human Genetics, University of Michigan, Michigan, Ann Arbor, USA \\ 2Laboratory of Stem Cell Biology and Developmental Genetics, The Francis Crick Institute, London, UK
}

Correspondence should be addressed to K Rizzoti: karine.rizzoti@crick.ac.uk

\begin{abstract}
In the last 15 years, single-cell technologies have become robust and indispensable tools to investigate cell heterogeneity. Beyond transcriptomic, genomic and epigenome analyses, technologies are constantly evolving, in particular toward multi-omics, where analyses of different source materials from a single cell are combined, and spatial transcriptomics, where resolution of cellular heterogeneity can be detected in situ. While some of these techniques are still being optimized, single-cell RNAseq has commonly been used because the examination of transcriptomes allows characterization of cell identity and, therefore, unravel previously uncharacterized diversity within cell populations. Most endocrine organs have now been investigated using this technique, and this has given new insights into organ embryonic development, characterization of rare cell types, and disease mechanisms. Here, we highlight recent studies, particularly on the hypothalamus and pituitary, and examine recent findings on the pancreas and reproductive organs where many single-cell experiments have been performed.
\end{abstract}

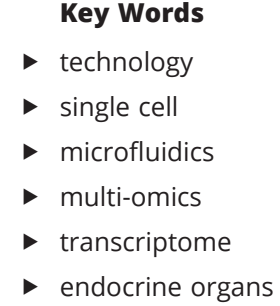

\section{Introduction}

Single-cell technologies have become an essential tool, offering an unprecedented glimpse into cellular heterogeneity. The decreasing costs of next generation sequencing, allowing the sequencing of millions or billions of DNA fragments in parallel, and the development of microfluidic techniques, easing the handling of a large number of single cells, both underlaid the emergence and success of relevant new technologies over the last 15 years. Among single-cell technologies, transcriptomic (scRNAseq) analyses are most frequently performed, followed by genome and epigenome sequencing. As new technologies are constantly emerging, and progressing very rapidly, the proteome and metabolome may also soon be analyzed at the single-cell level (Palii et al. 2019) (for review see Duncan et al. 2019). In parallel, multiomics technologies are utilized to profile simultaneously different material sources from one single cell, enabling, for example, correlations between genomic mutations and alteration of gene expression using G\&T-seq (Genome and Transcriptome-seq; Macaulay et al. 2015; for review see Macaulay et al. 2017). Furthermore, combining scRNA-seq with genome-editing tools, genetic screens can now be conducted with an unprecedented level of characterization using tools such as PERTURB-seq (Dixit et al. 2016), CRISP-seq (Jaitin et al. 2016) and CROP-seq (Datlinger et al. 2017). While one obvious 
caveat of most of these analyses is the loss of spatial information, because most techniques rely on the physical isolation of single cells or nuclei from their in vivo or in vitro context, progress has been made to solve this issue by performing in situ sequencing. Several different platforms, such as seqFISH (Eng et al. 2019), MERFISH (Chen et al. 2015), FiSSEQ (Lee et al. 2015) and TIVA (Lovatt et al. 2014), have been developed, and this technology is fast becoming accessible to the wider community (https://spatialtranscriptomics.com/).

To handle the large quantity of sequencing data generated from thousands up to hundreds of thousands of cells, specialized bioinformatic tools are essential. They need to be more sophisticated to deal with the particularities of single-cell datasets compared to bulk analyses, such as the low starting material, leading to enhanced noise and batch effects. Similar to bulk analyses, these tools are first used to check the quality of the data, remove noise, and generate the results, by aligning it to the relevant genome. More advanced algorithms, with the frequent development of new ones (Amezquita et al. 2019), are then used to extract as much information as possible from the sequencing data, to visualize results and extrapolate biological meaning. Essentially, the first step in result analysis is dimensional reduction, where cells with similar gene expression profiles are grouped together, allowing separation and, therefore, identification of distinct cell populations. Principal component analysis (PCA), t-distributed stochastic neighbour embedding (t-SNE) and uniform manifold approximation and projection (UMAP) are commonly used algorithms to achieve dimensional reduction. The Seurat package from the Satija lab comprises quality check and dimensional reduction analyses and is very commonly used to analyze single-cell RNA-seq datasets (Stuart et al. 2019). Then, according to the biological question, ordering of cell populations may be performed, because cells have been captured as they transit between different states or stages and this information can be used to reconstruct cellular hierarchies and trajectories. A commonly utilized algorithm to allow distribution of cells along a pseudo-time trajectory is Monocle from the Trapnell lab (Trapnell et al. 2014). Other widely used tools comprise RNA velocity, where trajectories are reconstituted according to the balance between unspliced and spliced transcripts, reflecting how recently a gene has been up-regulated (La Manno et al. 2018), and many others have been developed and extensively used (for review see Todorov \& Saeys 2019). Because the quantity of datasets generated is now exponential, bioinformatic tools are currently developed to allow comparisons between different datasets and platforms (Adey 2019). In this constantly evolving technological landscape, the range of possibilities is truly amazing. However, it is biological validation that gives meaning to dataset mining, and single-cell datasets are rather the beginning than the end of the story. Here, we will mostly focus our attention on transcriptome and genome analyses.

\section{Applications and remaining hurdles of single- cell genome and transcriptome analyses}

While the focus of this review will be on endocrine systems, we will first briefly review more widely the advances brought up by single-cell genomic and transcriptomic analyses. We will focus on pioneer studies and illustrate the areas where these technologies have been particularly instrumental in opening new avenues for investigation. Broadly, the immense advantage of single-cell approaches is that they highlight and inform about cell heterogeneity, while previous bulk analyses wiped away all this precious information (for review see Trapnell 2015). However, there are still technical hurdles. In genome analyses, allelic or locus dropouts and incomplete coverage lead to failed detection of singlenucleotide variants, while in transcriptome analyses, not all transcripts are reverse transcribed, and therefore, absence of a certain gene in the dataset does not always mean that it is not expressed. This is more of a problem for lowly transcribed genes, such as transcription factors. It clearly implies that a substantial amount of information is simply missing from the datasets. Spikeins (RNAs in known quantities) can be added as internal controls, but they may not always truly reflect the rate of capture of endogenous transcripts. Platforms, reagents and algorithms are constantly improved to respectively reduce and take into account these problems. For genome analysis, insertion of transposons for linear amplification (LIANTI) improves both coverage and fidelity compared with exponential amplification (Chen et al. 2017a). In addition, there are notable technological differences between the different platforms used for transcriptomic analyses (for review see Svensson et al. 2018). In term of results, the two main differences are sequencing depth (number of reads) and the number of cells processed, which are both inversely correlated (Ziegenhain et al. 2017). Maybe counterintuitively, it appears that sequencing more cells, at the detriment of the number of reads, is better for dimensional reduction. Furthermore, it is sometimes difficult to obtain a good quality single-cell 
suspension or this is simply not an option when working with frozen clinical samples. An alternative is to use single nuclei where transcriptome is comparable to that found in the cytoplasm, albeit less abundant, enriched in nuclear and ncRNA, and intronic sequences (Bakken et al. 2018).

The success of these technologies is illustrated by the proposal for ambitious projects such as the Human Cell Atlas, an international collaborative initiative aiming to complete characterization of all of the human body cell types (Regev et al. 2017). But, single-cell approaches have already made a significant impact on description, characterization, and therefore understanding of biological systems, while considerably expanding investigative possibilities.

In cancer research, identification of a tumor genomic mutational landscape at single-cell resolution allows reconstitution of cellular hierarchies, unravels tumoral evolution, and potentially, identifies the mutation at the origin of tumorigenesis (Navin et al. 2011, Wang et al. 2014). In pioneer scRNA-seq studies, an unanticipated heterogeneity, recapitulating neural development, was revealed in human glioblastoma. This was shown to be clinically relevant because higher heterogeneity in individual tumors is associated with lower survival (Patel et al. 2014), maybe reflecting a more primitive, undifferentiated and proliferative phenotype of the cells fueling tumor initiation and growth. Furthermore, rare cell types can be identified, such as circulating (CTC) and disseminated (DTC) tumor cells (Ni et al. 2013, Lohr et al. 2014). In addition, single-cell analyses allow segregation of stromal niche cells away from tumor cells, providing clues to understand how the microenvironment interact with the tumor cells. For example, in lung tumors, stromal cell RNAseq analyses uncovered complexity of this compartment and characterized new subpopulations (Lambrechts et al. 2018). In healthy subjects, investigation of the immune system in an innovative study (Villani et al. 2017) revealed the existence of a new type of dendritic cells that robustly activate T-cells and could therefore be utilized to strengthen anti-cancer immunity. Therefore, in a relatively short time, these new technologies have led to important discoveries in tumor and immune cell biology which are expected to impact significantly both the diagnosis and development of treatments.

Cell heterogeneity and trajectories are also central questions in stem cell and developmental biology. Better characterization of differentiation pathways is useful in vivo, in embryos and stem cells (SC), and in vitro, in embryonic SC (ESC) and induced pluripotent SC (iPSC) to improve disease modelling, drug screening assays, and ultimately for regenerative medicine. Single-cell approaches have thus been instrumental to resolve cell heterogeneity in different SC populations, such as neural stem cells (NSC) (Llorens-Bobadilla et al. 2015, Shin et al. 2015, Dulken et al. 2017, Kalamakis et al. 2019, Mizrak et al. 2019). They have given new insights into mechanisms of activation and metabolism in adult NSC (Llorens-Bobadilla et al. 2015, Shin et al. 2015, Dulken et al. 2017) and during aging (Kalamakis et al. 2019). These studies have also suggested that quiescent SC are poised for activation because some genes associated with commitment toward a certain cell fate are active in these, but only transcriptionally (for review see van Velthoven $\&$ Rando 2019). This changes our view of quiescence and thus strategies toward activation for regenerative purposes. In developing zebrafish (Wagner et al. 2018), frog (Briggs et al. 2018), mouse (Cao et al. 2019; PijuanSala et al. 2019) and human embryos (Xue et al. 2013, Yan et al. 2013, Blakeley et al. 2015, Leng et al. 2019), single-cell RNAseq have provided a further level of description of cell lineages emergence and cell-fate acquisition mechanisms. In addition, sophisticated approaches combining genome editing and scRNAseq have allowed reconstitution of developmental trajectories where single-cell progenies can be followed after integration in their genome of a unique barcode (Wagner et al. 2018). As we will show in the following section, these approaches have similarly remodelled pre-existing knowledge in endocrine organs. They moreover provide powerful tools to investigate normal and perturbed systems.

Broadly, these studies have often revealed an unanticipated degree of cellular heterogeneity at the transcriptional level. It is now important to examine whether this transcriptional diversity is translated at the protein level and therefore has a functional relevance. It is possible that transcriptional heterogeneity within cell populations simply reflects the presence of functionally distinct, stable sub-populations. Alternatively, transcriptional heterogeneity may highlight an unanticipated plasticity between different cell states or phenotypes. However, even if cases where this transcriptional diversity is not translated, such as in stem cells, where the presence of untranslated transcripts suggests a primed state toward differentiation (for review see van Velthoven \& Rando 2019), we still have much to learn from these data that reveal, in particular, the importance of post-transcriptional regulatory controls.

From the gonads to the pineal gland, most endocrine organs have now been sequenced at the single-cell level in different organisms and contexts (Table 1). 
Table 1 Summary illustrating single studies in endocrine systems.

Organ / discovery

\section{Endocrine pancreas}

Resource comparing in vivo progenitors and ES cell-derived ones (Krentz et al. 2018)

Characterization of murine pancreatic lineages emergence (Bastidas-Ponce et al. 2019)

Characterization of murine pancreatic lineages emergence (van Gurp et al. 2019)

Differential emergence and maturation of $\alpha$ and $\beta$ cells (Qiu et al. 2017)

Characterization of $\beta$ cells heterogeneity during post-natal expansion (Zeng et al. 2017)

Characterization and improvement of in vitro human $\beta$-cells differentiation (Veres et al. 2019)

Characterization of embryonic human pancreatic progenitors (Villani et al. 2019)

Comparison of mouse and human $\beta$ cells, characterization of $\beta$ cells heterogeneity (Baron et al. 2016)

Human adult pancreas atlas (Muraro et al. 2016)

Diabetic islet transcriptional profiles suggest dedifferentiation (Wang et al. 2016)

Transcriptomic changes associated with diabetes (Xin et al. 2016)

Transcriptomic changes associated with diabetes rare pancreatic cell types profile (Segerstolpe et al. 2016)

Increased transcriptional noise suggesting altered $\beta$ cell identity during aging (Enge et al. 2017)

\section{Male reproductive organs}

Transcriptional events surrounding male sex determination (Stevant et al. 2018)

Definition of spermatogenesis stage-specific markers and characterization of azoospermia in one patient (Wang et al. 2018)

Characterization of male meiosis and spermatogenesis (Hermann et al. 2018)

Adult mouse testis atlas (Green et al. 2018)

\section{Female reproductive organs and embryos}

Transcriptional heterogeneity of female germ cells (Vertesy et al. 2018)

Transcriptional changes during germ cell migration and gonadal somatic cells transcriptome heterogeneity (Guo et al. 2015)

Characterization of different stages during germ cells development and interactions with somatic cells (Li et al. 2017)

Effect of endometriosis on oocyte transcriptome (Ferrero et al. 2019)

Transcriptomic differences associated with PCOS in occytes and cumulus cells (Liu et al. 2016)

Transcriptional changes during folliculogenesis in oocytes and interaction with granulosa cells (Zhang et al. 2018)

Identification of organ cell types and changes associated with folliculogenesis (Fan et al. 2019)

\section{Origin of the cells}

Mouse embryonic and ES cell-derived pancreatic progenitors

Mouse embryonic pancreatic cells

Mouse embryonic pancreatic cells

Mouse embryonic and post-natal pancreatic cells

Mouse post-natal

pancreatic cells

Differentiating human iPS cells

Second trimester human pancreas

Adult human and mouse pancreatic cells

Adult human pancreas

Pediatric and adult pancreas from healthy and diabetic donors

Adult pancreas from healthy and diabetic donors

Adult pancreas from healthy and diabetic donors

Aging human pancreas

Mouse embryonic gonadal somatic cells

Testicular cells from normal and azoospermia patients

P6 and adult mice and adult human spermatogonial cells Adult mouse testes

Human fetal female gonadal cells

Human male and female gonadal cells

Human male and female gonadal cells

Oocytes from healthy and endometriosis patients Oocytes and granulosa cells from healthy and PCOS patients

Human oocytes and granulosa cells

Adult human ovaries

\section{Platform/methodology}

10X Genomics

10X Genomics

36,351

(van Gurp et al. 2019)

Smart-seq2

FluidigmC1

inDrop

$>100,000$

10X Genomics

8000

inDrop

12,000

Cell-seq2

1500

FluidigmC1

FluidigmC1

1492

Smart-seq2

(Enge et al. 2017)

2544

Fluidigm C1

Smart-seq2

Fluidigm C1

$>62,000$

Drop-seq

35,000

Smart-seq2

(Tang et al. 2010)

Smart-seq2

Smart-seq V4

Smart-seq2

48

(Wang et al. 2016)

10X genomics

56,206 
Table 1 Continued.

\section{Organ / discovery}

Transcriptional changes occurring during early development, determination of conserved and human specific events, characterization of parent-oforigin specific transcripts (Xue et al. 2013)

Comparison mouse-human early development and validation at the protein levels (Blakeley et al. 2015)

Parent-specific transcripts, effects on genome activation and early differentiation (Leng et al. 2019)

Differences between early embryonic stages progression and ES cells at different passages (Yan et al. 2013)

Uterus cell type characterization and effect of Hox gene loss (Mucenski et al. 2019)

Characterization of a proliferative effect of estrogen on ovarian epithelial cells (Vuong et al. 2018)

Characterization of endometrial progenitor cells and their potential role in uterine malformations and tumorgenesis (Saatcioglu et al. 2019)

Atlas of fetal-maternal interface during early gestation Human first-trimester placenta (Vento-Tormo et al. 2018)

Cell-type characterization in the human normal and pre-eclampsia placenta (Tsang et al. 2017)

Cell-type characterization in the human normal placenta (Pavlicev et al. 2017)

\section{Adrenals}

Characterization of cellular trajectories during Schwan cell precursors differentiation in the adrenal medulla (Furlan et al. 2017)

\section{Pituitary}

Gonadotroph cell line response to $\mathrm{GnRH}$ not linked to cell cycle (Ruf-Zamojski et al. 2018a)

$\mathrm{L} \beta \mathrm{T} 2$ cells respond to $\mathrm{GnRH}$ in bimodal all-or-nothing manner (Ruf-Zamojski et al. 2018b)

FoxP2 expression in gonadotrophs, and possible sterol-producing somatotroph subpopulation (Cheung et al. 2018)

Transcriptional similarity and diversity between related corticotrophs and melanotrophs (Mayran et al. 2019)

Novel posterior pituitary pituicyte markers (Chen et al. 2020)

Compensatory pituitary stem cell gene expression in genetic model of retinoic acid signaling inhibition (Cheung \& Camper 2020)

Transcriptional relationship between folliculostellate cells and hormone-producing cells

(Fletcher et al. 2019)

Detection of multihormonal cells; differential gene expression patterns between male and female mice, lactating and non-lactating females, and in an acromegalic mouse model (Ho et al. 2020)

\section{Origin of the cells}

Human and murine oocyte to morula stages

Human and murine zygote to blastocyst stage

Human biparental and uniparental zygote to morula stages

Human zygote to blastocyst stage and embryonic stem cells

WT and Hox9, 10,11 mutant mouse uteri

Cultured mouse ovarian

surface epithelial cells

Newborn rat uterine cells

Human placenta from

C-sections

Human placenta from

C-sections

Mouse neural crest derived embryonic adrenal medulla cells

GnRH- and control-treated L $\beta$ T2 10X Genomics gonadotroph cell line

$\mathrm{GnRH}$ - and control-treated L $\beta \mathrm{T} 2$ gonadotroph cell line

Seven-week-old C57BL/6] male whole pituitary

Four-month-old C57BL/6] male anterior and intermediate pituitary

Three-month-old C57BL/6 male 10X Genomics

intermediate and posterior pituitary

Whole pituitary from control and conditional knockout P4 female mice

Postpubertal Sprague-Dawley male and female whole pituitary

Eight-week-old CD1 male and female mice whole pituitary;8week-old acromegalic female pituitary ( $m t / G h r h$ transgenics);

13-week-old CD1 lactating and virgin female pituitary Fluidigm C1 and 10X genomics

10X Genomics

10X Genomics

Platform/methodology

Number of cells

sequenced

251

Integration of datasets from several studies 296

11,855

9801

70,000

20,518

87

$>1000$ (C1) and 6332 (10X)

13,663

10X Genomics

13,197

10X Genomics

6896

10X Genomics and 
Table 1 Continued.

\begin{tabular}{|c|c|c|c|}
\hline Organ / discovery & Origin of the cells & Platform/methodology & $\begin{array}{l}\text { Number of cells } \\
\text { sequenced }\end{array}$ \\
\hline \multicolumn{4}{|l|}{ Hypothalamus } \\
\hline $\begin{array}{l}\text { Spatial markers and developmental trajectories of } \\
\text { diencephalic progenitor cells (Guo \& Li 2019) }\end{array}$ & $\begin{array}{l}\text { EGFP-labeled diencephalon of } \\
\text { 12.5dpc Gbx2 creER-ires-eGfp } \\
\text { embryos }\end{array}$ & 10X Genomics & 7365 \\
\hline $\begin{array}{l}\text { Novel periventricular dopamine population that } \\
\text { responds to circadian rhythm-regulated neuromedin } \\
\text { S (Romanov et al. 2017) }\end{array}$ & $\begin{array}{l}\text { Central column of } \\
\text { hypothalamus in sections of } \\
\text { P14-28 C57BL6/N male and } \\
\text { female mouse brain }\end{array}$ & Fluidigm C1 & 3131 \\
\hline $\begin{array}{l}\text { Novel somatostatin population in lateral } \\
\text { hypothalamic area regulating repetitive locomotor } \\
\text { behavior (Mickelsen et al. 2019) }\end{array}$ & $\begin{array}{l}\text { Lateral hypothalamic area of } \\
\text { brain sections from P30 } \\
\text { C57BL/6 male and female } \\
\text { mice }\end{array}$ & 10X Genomics & 7218 \\
\hline $\begin{array}{l}\text { Novel arcuate somatostatin population regulating } \\
\text { feeding behavior; differential transcriptional } \\
\text { response to dietary changes between AgRP and } \\
\text { Pomc neurons (Campbell et al. 2017) }\end{array}$ & $\begin{array}{l}\text { Microdissected arcuate nucleus } \\
\text { and median eminence from } \\
\text { 4-12-week-old male and } \\
\text { female mice fed varying diets }\end{array}$ & Drop-seq & 20,921 \\
\hline $\begin{array}{l}\text { Markers of novel neuronal subtypes; differential } \\
\text { transcriptional responses to dietary changes } \\
\text { (Chen et al. 2017b) }\end{array}$ & $\begin{array}{l}\text { Dissected hypothalamus from } \\
\text { 8-10-week-old female B6D2F1 } \\
\text { mice on normal or restricted } \\
\text { diet }\end{array}$ & Drop-seq & 3319 \\
\hline $\begin{array}{l}\text { Identity and markers of novel neuronal populations } \\
\text { activated by specific social behaviors } \\
\text { (Moffitt et al. 2018) }\end{array}$ & $\begin{array}{l}\text { Preoptic hypothalamic area } \\
\text { from 78-week-old C57BL/6] } \\
\text { m-ale and female mice }\end{array}$ & 10X Genomics & 31,299 \\
\hline $\begin{array}{l}\text { Novel vascular progenitor in embryonic } \\
\text { hypothalamus (Hu et al. 2019) }\end{array}$ & $\begin{array}{l}\text { Hypothalamus of } 16.5 \mathrm{dpc} \\
\text { C57BL/6 embryos }\end{array}$ & 10X Genomics & 959 \\
\hline $\begin{array}{l}\text { Pineal gland } \\
\text { Identification of new pinealocyte subtypes and } \\
\text { circadian transcriptional differences } \\
\text { (Mays et al. 2018) }\end{array}$ & Rat whole pineal gland & 10X Genomics & 17,000 \\
\hline
\end{tabular}

Most studies have been performed in mice, but reports of human tissues sequencing are emerging. Studies have described organ development, such as sex determination (Stevant et al. 2018), allowed better characterization of rare cell types, like $\beta$-cells in the endocrine pancreas (DiGruccio et al. 2016) and approached disease mechanisms, by examining, for example, islets in diabetic patients (Baron et al. 2016, Muraro et al. 2016, Segerstolpe et al. 2016, Wang et al. 2016, Xin et al. 2016). Here, we will highlight recent studies, particularly those conducted on the hypothalamus and pituitary where the advances brought by these techniques have not been discussed yet, and examine recent advances in the pancreas and reproductive organs where most experiments have been performed.

\section{Single-cell analyses in the hypothalamo-pituitary axis}

The vast majority of cases of congenital hypopituitarism are of unknown origin. In these patients, hormonal deficiencies can result from either hypothalamic, pituitary or combined defects. The hypothalamus and pituitary gland form indeed the top two levels of the neuroendocrine axes and hold, therefore, significant potential for discovery using single-cell technologies, which have already begun in earnest. Both organs are critical for homeostatic maintenance of a range of physiological processes. The neuroendocrine axes control growth, lactation, reproduction, stress response, metabolism, and water retention, while hypothalamic neurons additionally connect to the CNS to regulate sleep, appetite, and body temperature (for review see Kelberman et al. 2009, Xie \& Dorsky 2017). The different cell types within both organs form functional networks controlling precise physiological functions. However, while a certain degree of organization underlines these networks, both in the hypothalamus and the pituitary, where cells are respectively organized in groups of neurons or nuclei, or interconnected in homotypic networks (Mollard et al. 2012), these are not morphologically apparent. Therefore single-cell approaches are particularly well-suited for identifying cell types and investigating the gene regulatory networks responsible for their fate and function. 


\section{Developmental origin of the hypothalamus}

The hypothalamus is a conserved vertebrate forebrain structure that, unlike some brain regions such as the cortex where the different layers are morphologically distinct, contains structurally contiguous nuclei, without physical/morphological boundaries/demarcation. A combination of competing Wnt, fibroblast growth factor (FGF), bone morphogenetic protein (BMP) and sonic hedgehog (SHH) signals pattern the diencephalon into the thalamus and the hypothalamus (for review see Xie \& Dorsky 2017, Blackshaw et al. 2010). A caudal portion of the ventral diencephalon evaginates toward the oral ectoderm-derived pituitary anlagen or Rathke's pouch, to form the infundibulum, which will give rise to the median eminence, pituitary stalk and posterior pituitary, thereby connecting the hypothalamus and pituitary gland into an integrated neuroendocrine unit. Different neuroendocrine cells reside in hypothalamic nuclei and some project axons through the arcuate nucleus and median eminence into the posterior pituitary. However, most neuroendocrine secretions are conveyed to the anterior pituitary by the hypophyseal portal system at the median eminence. A recent study performed scRNAseq of the developing diencephalon at $12.5 \mathrm{dpc}$ in mice (Guo \& Li 2019); however, the study focused on the molecular profiles of progenitors giving rise to the thalamus rather than the hypothalamus. Going forward, scRNAseq surveys of the ventral diencephalon throughout embryonic development will provide a deeper mechanistic understanding of the molecular pathways governing the patterning of the hypothalamus as well as the subsequent formation of neural circuits (for review see Blackshaw et al. 2010).

\section{Single-cell studies of the hypothalamus}

The adult hypothalamus contains a wide variety of neurons producing neurotransmitters and neuropeptide hormones, with some cell types grouped within distinct anatomical nuclei, while others are dispersed throughout large tracts of the hypothalamus. While this cellular diversity both among and within the different hypothalamic nuclei remained unclear, recent scRNAseq studies have focused on resolving the molecular landscape of each nuclei, leading to the discovery of novel neuronal subtypes. For example, dopamine (DA) neurons are located both in multiple dopaminergic cell groups (A11, A12, A14, A15) spread throughout the hypothalamus and also concentrated in the arcuate nucleus of the hypothalamus (for review see Ang 2006). SHH and BMP signaling pathways drive their specification (Ohyama et al. 2005), but little is known about the molecular differences between DA neurons that reside in different sites. Romanov et al. were one of the first to use scRNAseq in the hypothalamus (Romanov et al. 2017), identifying 62 neuronal cell-types in a central column of the medial-ventral hypothalamus, including four subtypes of dopamine neurons, one of which may regulate diurnal dopamine repression of prolactin release based on connections with suprachiasmatic neurons expressing Per genes. Furthermore, the arcuate nucleus and median eminence contain a high concentration of other neuroendocrine neurons, acting as the major control centers for neuroendocrine axes. A recent molecular census of these two nuclei identified 26 distinct neuronal cell types (Campbell et al. 2017) and additionally identified novel populations such as rare cells co-expressing transcripts for the orexigenic hormone agouti-related protein (AgRP) and the growth hormone-inhibiting factor somatostatin (Sst), two neuropeptide hormones generally thought to be expressed in distinct cell types. Whole hypothalamus scRNAseq identified molecular markers of neuronal subtypes including $\alpha$-tanycytes (Chen et al. $2017 b$ ), specialized glial cells lining the third ventricle that form the hypothalamic stem cell niche (Robins et al. 2013). Chen et al. further observed that food deprivation induced differential transcriptional effects on specific neuronal populations, pinpointing populations mostly affected by diet variation. In a later study, a massive survey of 1 million cells from the mouse hypothalamic preoptic region, combining scRNAseq and spatial transcriptomics, identified 66 neuronal subtypes (Moffitt et al. 2018). Furthermore, Moffitt et al. were able to identify the cells that were specifically activated during sexually dimorphic behaviors and their spatial organization, allowing further investigation of underlying neuronal circuits (Moffitt et al. 2018). In a more recent study, 30 classes of glutamineragic and GABAergic neurons were found in the lateral hypothalamic area by scRNAseq (Mickelsen et al. 2019), including sst-expressing neurons that, when selectively activated by designer receptors exclusively activated by designer drugs (DREADDs), induced a reduction in resting and an increase in repetitive locomotor behavior in mice. So far, few studies have used single-cell RNAseq to study the developing hypothalamus. One study utilized a newly developed clustering tool (PanoView) in the $16.5 \mathrm{dpc}$ hypothalamus to identify many expected cell-types and a novel vascular progenitor population (Hu et al. 2019), while a currently unpublished study performed scRNAseq at 12 timepoints between 10dpc and P45 to elucidate regional subdivisions of the hypothalamus and 
markers repressing and promoting hypothalamic fate (Kim 2019). These studies have provided rich resources for characterizing the cell populations existing within different regions of the hypothalamus, and future studies will likely turn toward understanding the biological role of these novel cell-types and subpopulations in health and disease.

\section{Development and cell-turnover in the pituitary gland}

The anterior and intermediate lobes of the pituitary gland are derived from the oral ectoderm as it invaginates upward toward the presumptive hypothalamus to form Rathke's pouch from about embryonic day $8.5 \mathrm{dpc}$ in response to BMP and FGF signaling from the ventral diencephalon (for review see Cheung et al. 2017). Over the course of development, pituitary progenitor/stem cells will diverge into distinct lineages to give rise to each of the six mature differentiated hormone cell-types (for review see Prince et al. 2011). The hypophyseal portal system arises from pituitary epithelial cells intercalating with endothelia cells from the surrounding mesenchyme to form the capillary network that, along the pituitary stalk, connect the hypothalamus to the pituitary (Hashimoto et al. 1998, Scully et al. 2016). The pituitary gland demonstrates remarkable plasticity during the lifetime of an animal, with cellular and physiological adaptations to adequately secrete the hormones required for specific life stages (for review see Florio 2011, Le Tissier et al. 2017). Modulation of hormone secretion is achieved at different levels, such as variation in hormone release, synthesis and storage, but also in endocrine cell numbers. While adult endocrine cells keep the ability to divide, their proliferative rate is low, but nonetheless sufficient, at least for corticotrophs, to ensure normal cell turnover (Langlais et al. 2013). However, upon physiological challenge (Rizzoti et al. 2013) or endocrine cell ablation (Fu et al. 2012), adult pituitary stem cells, normally quiescent in the adult, are able to give rise to new endocrine cells. Utilization of single-cell sequencing to study pituitary cells during all these different timepoints is currently in its infancy, but the increasing frequency of such studies over the past 2 years indicate it is likely to unveil significant novel discoveries in the years to come.

\section{Single-cell studies of the pituitary}

Single-cell RNA sequencing was first applied for pituitary studies using the L $\beta \mathrm{T} 2$ gonadotroph cell line, to dissect mechanisms of activation by GnRH (Ruf-Zamojski et al. 2018a). Cells transcriptional responses to GnRH were found to be highly variable and this was not linked to cell cycle progression (Ruf-Zamojski et al. 2018a). In a follow-up study (Ruf-Zamojski et al. 2018b), the authors refined their approach and suggest that responding L $\beta \mathrm{T} 2$ cells do not linearly increase gene transcription, but respond bimodally to rising GnRH concentrations (RufZamojski et al. 2018a). However, it is unclear whether gonadotrophs in vivo exhibit this behavior as well and what its functional consequence may be. Single-cell RNAseq is increasingly being applied to study primary pituitary tissues. Cheung et al. (Cheung et al. 2018) first described the identification of known pituitary populations and novel biomarkers, with computational analysis to suggest a sterol-producing subpopulation of growth hormoneproducing somatotrophs. In another study (Mayran et al. 2019), Mayran and colleagues utilized single-cell RNA sequencing as part of a wider study to understand transitional and epigenetic differences between melanotrophs and corticotrophs, both of which transcribe the prohormone pro-opiomelanocortin. Fletcher et al. microdissected anterior pituitaries from postpubertal male and female rats, finding a much larger proportion of S100ß-expressing folliculostellate cells (FSCs) than expected (Fletcher et al. 2019). Folliculostellate cells are a glial-cell like population forming a network throughout the gland. They have been shown to have an endocrine cell-supporting function and are hypothesized to optimize and harmonize endocrine secretion across the gland (Fauquier et al. 2002). In addition, they express the stem cell marker SOX2, but it is so far unclear whether they also have stem cell properties (Fauquier et al. 2008, Andoniadou et al. 2013). Fletcher et al. distinguished two subtypes of FSCs, although they do not yet provide a description of the transcriptomic differences between the two types. It is possible that the two FSC populations represent the differentially located S100b/SOX2-expressing cells in the marginal zone and the pituitary parenchyma, which as yet are not known to be functionally distinct in vivo. There is longstanding evidence for multihormonal cell types in the pituitary gland that produce more than one of the characteristic anterior pituitary hormones, such as mammosomatotrophs that express both growth hormone and prolactin (Frawley et al. 1985, Leong et al. 1985). However, there are virtually no known genetic markers to distinguish these populations from their single-hormone counterparts. Remarkably, while three pituitary scRNAseq studies did not find evidence of mammosomatotrophs (Cheung et al. 2018, Fletcher et al. 2019, Mayran et al. 2019), 
one single-cell study using 8-week-old WT CD1 male and female mice detected that approximately 30\% of cells expressing either $\mathrm{Gh}$ or $\mathrm{Prl}$ also expressed the other hormone in both sexes (Ho et al. 2020). Furthermore, this study also appeared to show that the majority of Pomc-expressing cells also express $\mathrm{Gh}$ and $\mathrm{Prl}$ and that the majority of Tshb-expressing cells also express $G h$. It is unclear why multihormone pituitary cells are so variably detected in different studies. Further studies are required to confirm and characterize these plurihormonal cells, but single-cell approaches have the potential to identify markers and thus allow us to characterize and better understand the role of these cells. Ho et al. also explored differential gene expression patterns between males and females, lactating and virgin adult female mice, and in an acromegalic mouse model (Ho et al. 2020). Recently a study also utilized scRNAseq to characterize the post-natal consequences of retinoic acid inhibition in the pituitary. These analyses showed a compensatory expression of adhehyde dehydrogenase in the stem cell compartment, while there was no manifestation of pituitary disease in this genetic model of retinoic acid inhibition (Cheung \& Camper 2020). Furthermore, the first scRNAseq study of the posterior pituitary identified novel markers of pituicytes, a specialized posterior pituitary astroglia celltype (Chen et al. 2020).

In conclusion, due to the novelty of single-cell studies in pituitary tissue, the functional role of novel genes identified in individual cell types has yet to be investigated. Because most cases of hypopituitarism are of unknown aetiology, these studies have the potential to identify new regulators of endocrine cell fate and function. While a previous study has studied pituitary tumors on the single-cell level using single-cell calcium imaging and immunohistochemistry (Senovilla et al. 2015), scRNAseq is likely to prove powerful in understanding the molecular origins of different types of pituitary tumors (Muller 2014, Molitch 2017).

\section{Single-cell studies in the pancreas}

The endocrine pancreas has a central role in maintaining and adapting the blood glucose concentration in vertebrates. The islets of Langerhans that form the endocrine pancreas comprise five main different cell types: $\alpha$ cells producing glucagon, $\beta$ cells secreting insulin, $\delta$ cells synthesizing sst, $\varepsilon$ cells making ghrelin and $\gamma$ cells, source of pancreatic polypeptide. Diabetes, resulting from a failure to control blood glucose concentration, results from $\beta$-cells deficiency and it afflicts more than
$8 \%$ of the world population aged over 18 years (WHO). It is incurable, and while current treatments reduce symptoms, there are long-term complications. A major goal is to stop its progression and restore $\beta$ cells (for review see Zhou \& Melton 2018). It is therefore not surprising that, among endocrine organs, the pancreas has been by far the most investigated gland at the single-cell level. Single-cell technologies appear indeed particularly suited to understand the underlying mechanisms and functional significance of pancreatic $\beta$-cell heterogeneity, in both health and disease. With the ultimate goal to generate new $\beta$ cells for diabetic patients, either in vitro, for transplantation, or in vivo by stimulating regeneration or trans-differentiation, single-cell studies have already provided valuable insights. We will present here a concise review of representative studies and refer readers to recent and more comprehensive reviews (Carrano et al. 2017, Tritschler et al. 2017).

\section{Morphogenesis and cell turnover}

Embryonically, the pancreas is a foregut endoderm derivative (Jennings et al. 2015, Larsen \& Grapin-Botton 2017). Several single-cell RNAseq datasets have now been generated, using different strategies, to further unravel endocrine developmental pathways (Krentz et al. 2018, Bastidas-Ponce et al. 2019, van Gurp et al. 2019). At $9.5 \mathrm{dpc}$ in the mouse, signals from the mesoderm induce the formation of buds from the primitive gut endoderm. From these buds, an intensive branching develops, invading and interacting with the surrounding mesenchyme, ultimately giving rise to epithelial monolayers organized around a single lumen. At the tips of the branches, endocrine progenitors differentiate from neurogenin-3 unipotent progenitors. From 9.5dpc until birth, committed precursors delaminate from the epithelium and cluster to form the islets of Langerhans just before birth. Post-natally, there is proliferation, in particular of endocrine cells, to reach the mature organ size, but after this early phase, proliferation and cell turnover are low and there is clearly a limited regenerative potential in humans. $\beta$-cell turnover appears to rely on division of pre-existing $\beta$ cells, but ablation studies in the mouse have highlighted the potential of $\alpha$ and $\delta$ to transdifferentiate into insulin-producing cells. In human, $\alpha$ and $\delta$ cells have recently been successfully reprogrammed in vitro into $\beta$ cells, highlighting the conservation of this phenotypic plasticity and its potential use for therapeutic approaches (Furuyama et al. 2019). The presence of an adult population of islet stem cells has been suggested 
based on histological observations; however, there is not, so far, any convincing experimental evidence of their existence (Zhou \& Melton 2018). This is in contrast with the exocrine pancreas, where scRNAseq analyses have helped to uncover a small population with progenitor characteristics (Wollny et al. 2016).

\section{Single-cell RNAseq studies}

$\beta$ cells are known to be a highly heterogeneous population, especially post-natally because there is substantial organ growth in rodents and cells are at different stages of maturation. Therefore, to characterize mechanisms underlying efficient $\beta$-cell generation at these early stages, single-cell analyses are useful to segregate the different cell states and arrange them along a differentiation trajectory. To unravel these early events, scRNAseq was performed at multiple timepoints post-natally in the mouse (Qiu et al. 2017, Zeng et al. 2017). Together, these two studies highlight new maturity markers and proliferation pathways that are active early on. The latter ones could be used and be re-activated in the adult to potentially stimulate endogenous regeneration. As mentioned earlier, $\delta$ cells have the potential to trans-differentiate into $\beta$ cells both in mice and humans (Furuyama et al. 2019). However, because they are a rare cell type, many questions remain about their function. ScRNAseq helped to show that they are important regulators of $\beta$ cells through their unique ability to respond to Ghrelin (DiGruccio et al. 2016, Xin et al. 2016).

Most studies have been expectedly performed in mice, but it is particularly important to examine human pancreas because there are substantial known differences between both species. Single-cell analyses have thus been used to characterize human islets during development (Petersen et al. 2017, Ramond et al. 2018, Villani et al. 2019) and in both healthy and diabetic post-natal tissues (Baron et al. 2016, Muraro et al. 2016, Segerstolpe et al. 2016, Wang et al. 2016, Xin et al. 2016). These analyses have revealed an unanticipated complexity within the cell populations, particularly from the diseased samples. However, similar subpopulations were identified between the different datasets, along with characterization of transitional states, opening new avenues for potential treatments (for review see Dominguez-Gutierrez et al. 2019). Finally, aging in the healthy pancreas is associated with an accumulation of somatic mutations and an increased transcriptional noise which may reflect a compromised islet identity (Enge et al. 2017). It is not yet known how the diseased pancreas evolves with time.

(c) 2020 Society for Endocrinology Published by Bioscientifica Ltd. Printed in Great Britain
Single-cell approaches have also been used to assess the protocol and quality of $\beta$ cells generated in vitro. The comparison of datasets generated from fetal human samples with those generated in vitro highlighted differences and confirmed the inability to reach a fully mature state (Hrvatin et al. 2014, Petersen et al. 2017, Ramond et al. 2018), which remains a problem for most differentiation protocols. A similar conclusion was made comparing scRNAseq mouse embryonic datasets with ones obtained from $\beta$ cells derived from human ES cells (Krentz et al. 2018). Comparisons between in vivo development and in vitro differentiation are useful to pinpoint steps where differences exist and where improvements are required. Finally, more than 100,000 human pluripotent stem cells were recently analyzed during 3D pancreatic endocrine differentiation (Veres et al. 2019). These extensive datasets reveal intermediate differentiation states, better markers and guide toward further improvements to obtain more mature $\beta$ cells (Veres et al. 2019).

The exocrine pancreas secretes digestive enzymes through the pancreatic duct. The pancreatic duct is also the site of the most common pancreatic tumors. Pancreatic ductal carcinomas are often discovered late, and therefore, the prognosis is poor and these tumors represent the fourth highest cause of cancer-related deaths (Foucher et al. 2018). Single-cell RNAseq approaches have been used to resolve tumor heterogeneity, characterize new markers for prognosis, and pinpoint potential target and immune anti-tumor strategies (Peng et al. 2019). In addition, datasets have been generated from precursor lesions to describe events preceding tumorigenesis and characterize markers (Bernard et al. 2019).

In conclusion, most efforts have been focalized toward the generation or re-generation of $\beta$ cells, and single-cell analyses have certainly provided clues on how to improve current protocols. Single-cell characterization of diabetes has highlighted an unexpected heterogeneity between patients, and more work is needed to reveal the biological significance of these results and pinpoint common features that could be used to improve current treatments.

\section{Single-cell analyses in reproductive organs}

About one in eight women and one in ten men have experienced infertility in the UK between 2010 and 2012 (Datta et al. 2016). In males, tests, diagnosis and treatments are not standardized, and in 2017, the WHO recommended that more research was needed to better characterize germ cells and the effect of lifestyle choices on their differentiation and functionality (Barratt et al. 2017). 
In women, infertility causes are unknown in about 25\% of the cases (Somigliana et al. 2016). Because infertility is associated in particular with implantation failure, a better characterization of the female reproductive organs and modalities of embryonic implantation are required. Single-cell technologies have moreover been used to investigate mechanisms of sex determination, and this subject has been recently reviewed (Stevant \& Nef 2018). Here, we will instead focus on discoveries made using single-cell analyses of germ and supporting cells, the uterus and early stages of pregnancy.

\section{Mechanisms of sex determination}

In mammals, the undifferentiated gonad adopts a male differentiation pathway upon expression of the $\mathrm{Y}$ chromosome sex determination factor SRY, at $10.5 \mathrm{dpc}$ in the mouse. Its expression is restricted to the NR5A1 positive presumptive Sertoli cells, a spermatogenesis-supporting cell type. A recent single-cell analysis analyzed these early events and examined the transcriptome of NR5A1 positive cells from 10.5 to $16.5 \mathrm{dpc}$ in the mouse (Stevant et al. 2018). The authors show that these cells are multipotent and that, in the male, they give rise sequentially to Sertoli then Leydig cells, interstitial cells producing testosterone (Stevant et al. 2018). The mechanisms explaining this shift in cell fate are currently unknown, but because deficiency/ malfunction in Sertoli, and more frequently Leydig cells underlie infertility, these results have important clinical implications. In XX embryos, the transcription factor Foxl2 and the Wnt signaling pathways are thought to be crucial determinants. At the time of sex determination, between 10 and $11 \mathrm{dpc}$, primordial germ cells, originating from the post-implantation epiblast, migrate through the endoderm to the gonads. Male and female specific differentiation pathways subsequently antagonize each other to promote development of the gonad and associated organs and tissues characteristic of genetic sex of the individual and actively prevent the alternative process. For example, the Mullerian ducts, that will give rise to the uterus, develop along the Wolfian ducts, that will later degenerate in the female, while in the male, presumptive Sertoli cells secrete the anti-Mullerian hormone (AMH) causing Mullerian ducts regression, whereas the Wolfian ducts give rise to the vas deferens.

\section{Single-cell RNAseq studies}

Testicular cells have been analyzed both in mouse (Green et al. 2018) at different stages (Hermann et al. 2018) and in humans, in both healthy (Hermann et al. 2018) and unfertile subjects (Wang et al. 2018). In the mouse, scRNAseq analyses of testicular cells provide a thorough description of spermatogenesis (Green et al. 2018, Hermann et al. 2018) and of supporting cells, revealing new subtypes (Green et al. 2018). In addition, differences between juvenile and adult mouse spermatogenesis have been transcriptionally characterized (Hermann et al. 2018). These will be useful when trying to devise in vitro approaches for germ cell differentiation (Zhou et al. 2016). In human, these analyses allow better description of pathologies, as demonstrated by Wang et al. who characterized abnormal gene expression patterns in Sertoli cells when comparing expression profiles from testicular cells in normal and azoospermic samples (Wang et al. 2018). A similar approach was used to characterize the effects of endometriosis in females. Endometriosis causes infertility, because adherences develop in the female reproductive tract. However, it has also been suggested to affect oocyte quality. Its impact on oocyte was thus evaluated using scRNAseq (Ferrero et al. 2019). These analyses revealed that the disease affects oocyte transcriptomes and that these changes suggested a reduced quality (Ferrero et al. 2019). Oocytes and granulosa cells were similarly investigated in normal and polycystic ovary syndrome (PCOS) samples and the positive impact of fertility treatments detected at the transcriptional level (Liu et al. 2016). Human folliculogenesis was moreover examined in several studies to better characterize oocyte activation and cell interactions in the ovary, in particular with the supporting granulosa cells and the steroidogenic theca cells (Zhang et al. 2018, Fan et al. 2019). These analyses provide a precise description of these processes. They also suggest new markers of ovarian reserve which could be used as fertility assessors (Zhang et al. 2018) and provide a thorough description of the different ovarian somatic cell types (Fan et al. 2019). Important epigenome changes, such as X-chromosome re-activation in the female, are observed during meiosis. Several studies have examined these changes in human male and female primordial germ cells at the single-cell level by performing exome, methylome and transcriptome analyses (Guo et al. 2015, Li et al. 2017, Vertesy et al. 2018) to understand mechanisms of reprogramming underlining germ cell development. Furthermore, preimplantation embryonic stages have also been examined in mouse and human, in several studies, characterizing mechanisms of genome re-activation, early cleavage processes and speciesdependant differences (Xue et al. 2013, Yan et al. 2013, Blakeley et al. 2015, Leng et al. 2019). Finally, anomalies of the uterus are estimated to account for a fifth of female 
infertility cases. ScRNAseq was used in mice to examine development of this organ in juvenile animals (Mucenski et al. 2019, Saatcioglu et al. 2019). In humans, the maternalfetal interface has been characterized by performing singlecell sequencing of the placenta and decidua during the first trimester of pregnancy, focusing on characterization of cellular interactions to better understand mechanisms underlining development of this complex and transient environment (Vento-Tormo et al. 2018). Studies were also performed on placenta at term (Pavlicev et al. 2017), in particular to characterize anomalies characterizing preeclampsia (Tsang et al. 2017).

In conclusion, single-cell studies have so far been used to unravel sex determination mechanisms and characterize conditions underlying infertility. It is expected that these discoveries will lead to improved treatments and care.

\section{Conclusion}

The robustness of new single-cell technologies has enabled analyses of an unprecedented numbers of singlecells from heterogeneous tissue systems. While technical hurdles remain, the impact of these technologies is already obvious and it is expected to further increase, along with technological advances. Multi-omic approaches are expected to expand investigative potential, while spatial transcriptomic approaches will allow examination of cell heterogeneity in situ. In parallel, it will also be important to examine whether this transcriptional diversity within cell populations underlines functional differences or maybe simply highlight different cell states. Furthermore, the potential of these technologies for characterization of mutant phenotypes and disease mechanisms appear particularly interesting because both the cells that are directly affected and their potential effect on surrounding cells can be distinguished. In particular, single-cell analyses of tumor development in endocrine organs should help characterize these diseases and potentially point toward new therapeutic approaches. While many studies have so far characterized normal organ cell heterogeneity, these technologies hold great potential for further functional characterization in different contexts.

\section{Declaration of interest}

The author declares that there is no conflict of interest that could be perceived as prejudicing the impartiality of this review.

\section{Funding}

This work was supported by the Francis Crick Institute which receives its core funding from Cancer Research UK (FC001107), the UK Medical
Research Council (FC001107), and the Wellcome Trust (FC001107) (Rizzoti/ Robin Lovell-Badge), and the National Institute of Health R01HD34283 and R01HD30428 (Cheung/Sally A. Camper).

\section{Acknowledgements}

The authors are grateful to Probir Chakravarty and Robin Lovell-Badge for helpful comments.

\section{References}

Adey AC 2019 Integration of single-cell genomics datasets. Cell 177 1677-1679. (https://doi.org/10.1016/j.cell.2019.05.034)

Amezquita RA, Lun ATL, Becht E, Carey VJ, Carpp LN, Geistlinger L, Marini F, Rue-Albrecht K, Risso D, Soneson C, et al. 2019 Orchestrating single-cell analysis with bioconductor. Nature Methods 17 137-145. (https://doi.org/10.1038/s41592-019-0654-x)

Andoniadou CL, Matsushima D, Mousavy Gharavy SN, Signore M, Mackintosh AI, Schaeffer M, Gaston-Massuet C, Mollard P, Jacques TS, Le Tissier P, et al. 2013 Sox2(+) stem/progenitor cells in the adult mouse pituitary support organ homeostasis and have tumor-inducing potential. Cell Stem Cell 13 433-445. (https://doi. org/10.1016/j.stem.2013.07.004)

Ang SL 2006 Transcriptional control of midbrain dopaminergic neuron development. Development 133 3499-3506. (https://doi.org/10.1242/ dev.02501)

Bakken TE, Hodge RD, Miller JA, Yao Z, Nguyen TN, Aevermann B, Barkan E, Bertagnolli D, Casper T, Dee N, et al. 2018 Single-nucleus and single-cell transcriptomes compared in matched cortical cell types. PLoS One 13 e0209648. (https://doi.org/10.1371/journal. pone.0209648)

Baron M, Veres A, Wolock SL, Faust AL, Gaujoux R, Vetere A, Ryu JH, Wagner BK, Shen-Orr SS, Klein AM, et al. 2016 A single-cell transcriptomic map of the human and mouse pancreas reveals interand intra-cell population structure. Cell Systems 3 346-360.e4. (https://doi.org/10.1016/j.cels.2016.08.011)

Barratt CLR, Bjorndahl L, De Jonge CJ, Lamb DJ, Osorio Martini F, Mclachlan R, Oates RD, Van Der Poel S, St John B, Sigman M, et al. 2017 The diagnosis of male infertility: an analysis of the evidence to support the development of global WHO guidance-challenges and future research opportunities. Human Reproduction Update $\mathbf{2 3}$ 660-680. (https://doi.org/10.1093/humupd/dmx021)

Bastidas-Ponce A, Tritschler S, Dony L, Scheibner K, Tarquis-Medina M, Salinno C, Schirge S, Burtscher I, Bottcher A, Theis FJ, et al. 2019 Comprehensive single cell mRNA profiling reveals a detailed roadmap for pancreatic endocrinogenesis. Development 146 dev173849. (https://doi.org/10.1242/dev.173849)

Bernard V, Semaan A, Huang J, San Lucas FA, Mulu FC, Stephens BM, Guerrero PA, Huang Y, Zhao J, Kamyabi N, et al. 2019 Single-cell transcriptomics of pancreatic cancer precursors demonstrates epithelial and microenvironmental heterogeneity as an early event in neoplastic progression. Clinical Cancer Research 25 2194-2205. (https://doi.org/10.1158/1078-0432.CCR-18-1955)

Blackshaw S, Scholpp S, Placzek M, Ingraham H, Simerly R \& Shimogori T 2010 Molecular pathways controlling development of thalamus and hypothalamus: from neural specification to circuit formation. Journal of Neuroscience 30 14925-14930. (https://doi. org/10.1523/JNEUROSCI.4499-10.2010)

Blakeley P, Fogarty NM, Del Valle I, Wamaitha SE, Hu TX, Elder K, Snell P, Christie L, Robson P \& Niakan KK 2015 Defining the three cell lineages of the human blastocyst by single-cell RNA-seq. Development 142 3151-3165. (https://doi.org/10.1242/dev.123547)

Briggs JA, Weinreb C, Wagner DE, Megason S, Peshkin L, Kirschner MW \& Klein AM 2018 The dynamics of gene expression in vertebrate 
embryogenesis at single-cell resolution. Science $\mathbf{3 6 0}$ eaar5780 (https://doi.org/10.1126/science.aar5780)

Campbell JN, Macosko EZ, Fenselau H, Pers TH, Lyubetskaya A, Tenen D, Goldman M, Verstegen AM, Resch JM, Mccarroll SA, et al. 2017 A molecular census of arcuate hypothalamus and median eminence cell types. Nature Neuroscience 20 484-496. (https://doi. org/10.1038/nn.4495)

Cao J, Spielmann M, Qiu X, Huang X, Ibrahim DM, Hill AJ, Zhang F, Mundlos S, Christiansen L, Steemers FJ, et al. 2019 The single-cell transcriptional landscape of mammalian organogenesis. Nature 566 496-502. (https://doi.org/10.1038/s41586-019-0969-x)

Carrano AC, Mulas F, Zeng C \& Sander M 2017 Interrogating islets in health and disease with single-cell technologies. Molecular Metabolism 6 991-1001. (https://doi.org/10.1016/j. molmet.2017.04.012)

Chen KH, Boettiger AN, Moffitt JR, Wang S \& Zhuang X 2015 RNA imaging. Spatially resolved, highly multiplexed RNA profiling in single cells. Science 348 aaa6090. (https://doi.org/10.1126/science. aaa6090)

Chen C, Xing D, Tan L, Li H, Zhou G, Huang L \& Xie XS 2017a Singlecell whole-genome analyses by linear amplification via transposon insertion (LIANTI). Science 356 189-194. (https://doi.org/10.1126/ science.aak9787)

Chen R, Wu X, Jiang L \& Zhang Y 2017b Single-cell RNA-seq reveals hypothalamic cell diversity. Cell Reports 18 3227-3241. (https://doi. org/10.1016/j.celrep.2017.03.004)

Chen Q, Leshkowitz D Blechman J \& Levkowitz G 2020 Single-cell molecular and cellular architecture of the mouse neurohypophysis. eNeuro 7 ENEURO.0345-19.2019. (https://doi.org/10.1523/ ENEURO.0006-20.2020)

Cheung LY, Davis SW, Brinkmeier ML, Camper SA \& Perez-Millan MI 2017 Regulation of pituitary stem cells by epithelial to mesenchymal transition events and signaling pathways. Molecular and Cellular Endocrinology 445 14-26. (https://doi.org/10.1016/j. mce.2016.09.016)

Cheung LYM \& Camper SA 2020 PROP1-dependent retinoic acid signaling regulates developmental pituitary morphogenesis and hormone expression. Endocrinology 161 bqaa002. (https://doi. org/10.1210/endocr/bqaa002)

Cheung LYM, George AS, Mcgee SR, Daly AZ, Brinkmeier ML, Ellsworth BS \& Camper SA 2018 Single-cell RNA sequencing reveals novel markers of male pituitary stem cells and hormone-producing cell types. Endocrinology 159 3910-3924. (https://doi.org/10.1210/ en.2018-00750)

Datlinger P, Rendeiro AF, Schmidl C, Krausgruber T, Traxler P, Klughammer J, Schuster LC, Kuchler A, Alpar D \& Bock C 2017 Pooled CRISPR screening with single-cell transcriptome readout. Nature Methods 14 297-301. (https://doi.org/10.1038/nmeth.4177)

Datta J, Palmer MJ, Tanton C, Gibson LJ, Jones KG, Macdowall W, Glasier A, Sonnenberg P, Field N, Mercer CH, et al. 2016 Prevalence of infertility and help seeking among 15000 women and men. Human Reproduction 31 2108-2118. (https://doi.org/10.1093/humrep/dew123)

Digruccio MR, Mawla AM, Donaldson CJ, Noguchi GM, Vaughan J, Cowing-Zitron C, Van Der Meulen T \& Huising MO 2016 Comprehensive alpha, beta and delta cell transcriptomes reveal that ghrelin selectively activates delta cells and promotes somatostatin release from pancreatic islets. Molecular Metabolism 5 449-458. (https://doi.org/10.1016/j.molmet.2016.04.007)

Dixit A, Parnas O, Li B, Chen J, Fulco CP, Jerby-Arnon L, Marjanovic ND, Dionne D, Burks T, Raychowdhury R, et al. 2016 Perturb-Seq: dissecting molecular circuits with scalable single-cell RNA profiling of pooled genetic screens. Cell 167 1853-1866.e17. (https://doi.org/10.1016/j.cell.2016.11.038)

Dominguez-Gutierrez G, Xin Y \& Gromada J 2019 Heterogeneity of human pancreatic beta-cells. Molecular Metabolism 27S S7-S14. (https://doi.org/10.1016/j.molmet.2019.06.015)
Dulken BW, Leeman DS, Boutet SC, Hebestreit K \& Brunet A 2017 Single-cell transcriptomic analysis defines heterogeneity and transcriptional dynamics in the adult neural stem cell lineage. Cell Reports 18 777-790. (https://doi.org/10.1016/j.celrep.2016.12.060)

Duncan KD, Fyrestam J \& Lanekoff I 2019 Advances in mass spectrometry based single-cell metabolomics. Analyst 144 782-793. (https://doi.org/10.1039/C8AN01581C)

Eng CL, Lawson M, Zhu Q, Dries R, Koulena N, Takei Y, Yun J, Cronin C, Karp C, Yuan GC, et al. 2019 Transcriptome-scale superresolved imaging in tissues by RNA seqFISH. Nature 568 235-239. (https://doi.org/10.1038/s41586-019-1049-y)

Enge M, Arda HE, Mignardi M, Beausang J, Bottino R, Kim SK \& Quake SR 2017 Single-cell analysis of human pancreas reveals transcriptional signatures of aging and somatic mutation patterns. Cell 171 321-330.e14. (https://doi.org/10.1016/j.cell.2017.09.004)

Fan X, Bialecka M, Moustakas I, Lam E, Torrens-Juaneda V, Borggreven NV, Trouw L, Louwe LA Pilgram GSK, Mei H, et al. 2019 Single-cell reconstruction of follicular remodeling in the human adult ovary. Nature Communications 10 3164. (https://doi. org/10.1038/s41467-019-11036-9)

Fauquier T, Lacampagne A, Travo P, Bauer K \& Mollard P 2002 Hidden face of the anterior pituitary. Trends in Endocrinology and Metabolism 13 304-309. (https://doi.org/10.1016/S1043-2760(02)00616-1)

Fauquier T, Rizzoti K, Dattani M, Lovell-Badge R \& Robinson IC 2008 SOX2-expressing progenitor cells generate all of the major cell types in the adult mouse pituitary gland. PNAS 105 2907-2912. (https:// doi.org/10.1073/pnas.0707886105)

Ferrero H, Corachan A, Aguilar A, Quinonero A, Carbajo-Garcia MC, Alama P, Tejera A, Taboas E, Munoz E, Pellicer A, et al. 2019 Singlecell RNA sequencing of oocytes from ovarian endometriosis patients reveals a differential transcriptomic profile associated with lower quality. Human Reproduction 34 1302-1312. (https://doi.org/10.1093/ humrep/dez053)

Fletcher PA, Smiljanic K, Maso Previde R, Iben JR, Li T, Rokic MB, Sherman A, Coon SL \& Stojilkovic SS 2019 Cell type- and sexdependent transcriptome profiles of rat anterior pituitary cells. Frontiers in Endocrinology 10 623. (https://doi.org/10.3389/ fendo.2019.00623)

Florio T. 2011 Adult pituitary stem cells: from pituitary plasticity to adenoma development. Neuroendocrinology 94 265-277. (https://doi. org/10.1159/000330857)

Foucher ED, Ghigo C, Chouaib S, Galon J, Iovanna J \& Olive D. 2018 Pancreatic ductal adenocarcinoma: A strong imbalance of good and bad immunological cops in the tumor microenvironment. Frontiers in Immunology 9 1044. (https://doi.org/10.3389/fimmu.2018.01044)

Frawley LS, Boockfor FR \& Hoeffler JP 1985 Identification by plaque assays of a pituitary cell type that secretes both growth hormone and prolactin. Endocrinology 116 734-737. (https://doi.org/10.1210/ endo-116-2-734)

Fu Q, Gremeaux L, Luque RM, Liekens D, Chen J, Buch T, Waisman A, Kineman R \& Vankelecom H 2012 The adult pituitary shows stem/ progenitor cell activation in response to injury and is capable of regeneration. Endocrinology 153 3224-3235. (https://doi.org/10.1210/ en.2012-1152)

Furlan A, Dyachuk V, Kastriti ME, Calvo-Enrique L, Abdo H, Hadjab S, Chontorotzea T, Akkuratova N, Usoskin D, Kamenev D, et al. 2017 Multipotent peripheral glial cells generate neuroendocrine cells of the adrenal medulla. Science $\mathbf{3 5 7}$ eaal3753. (https://doi.org/10.1126/ science.aal3753)

Furuyama K, Chera S, Van Gurp L, Oropeza D, Ghila L, Damond N, Vethe H, Paulo JA, Joosten AM, Berney T, et al. 2019 Diabetes relief in mice by glucose-sensing insulin-secreting human alpha-cells. Nature 567 43-48. (https://doi.org/10.1038/s41586-019-0942-8)

Green CD, Ma Q, Manske GL, Shami AN, Zheng X, Marini S, Moritz L, Sultan C, Gurczynski SJ, Moore BB, et al. 2018 A comprehensive roadmap of murine spermatogenesis defined by single-cell RNA-Seq. 
Developmental Cell 46 651-667.e10. (https://doi.org/10.1016/j. devcel.2018.07.025)

Guo F, Yan L, Guo H, Li L, Hu B, Zhao Y, Yong J, Hu Y, Wang X, Wei Y, et al. 2015 The transcriptome and DNA methylome landscapes of human primordial germ cells. Cell 161 1437-1452. (https://doi. org/10.1016/j.cell.2015.05.015)

Guo Q \& Li JYH 2019 Defining developmental diversification of diencephalon neurons through single cell gene expression profiling. Development 146 dev174284. (https://doi.org/10.1242/ dev.174284)

Hashimoto H, Ishikawa H \& Kusakabe M 1998 Three-dimensional analysis of the developing pituitary gland in the mouse. Developmental Dynamics 212 157-166. (https://doi.org/10.1002/ (SICI) 1097-0177(199805)212:1<157::AID-AJA14>3.0.CO;2-4)

Hermann BP Cheng K, Singh A, Roa-De La Cruz L, Mutoji KN, Chen IC, Gildersleeve H, Lehle JD, Mayo M, Westernstroer B, et al. 2018 The mammalian spermatogenesis single-cell transcriptome, from spermatogonial stem cells to spermatids. Cell Reports $\mathbf{2 5}$ 1650-1667.e8. (https://doi.org/10.1016/j.celrep.2018.10.026)

Ho Y, Hu P, Peel MT, Chen S, Camara PG, Epstein DJ, Wu H \& Liebhaber SA 2020 Single-cell transcriptomic analysis of adult mouse pituitary reveals sexual dimorphism and physiologic demandinduced cellular plasticity. Protein Cell [epub]. (https://doi. org/10.1007/s13238-020-00705-x)

Hrvatin S, O'Donnell CW, Deng F, Millman JR, Pagliuca FW, Diiorio P, Rezania A, Gifford DK \& Melton DA 2014 Differentiated human stem cells resemble fetal, not adult, beta cells. PNAS 111 3038-3043. (https://doi.org/10.1073/pnas.1400709111)

Hrvatin S, Hochbaum DR, Nagy MA, Cicconet M, Robertson K, Cheadle L, Zilionis R, Ratner A, Borges-Monroy, Klein AM, et al. 2018 Single-cell analysis of experience-dependent transcriptomic states in the mouse visual cortex. Nature Neuroscience 21 120-129. (https://doi.org/10.1038/s41593-017-0029-5)

Hu MW, Kim DW, Liu S, Zack DJ, Blackshaw S \& Qian J 2019 PanoView: An iterative clustering method for single-cell RNA sequencing data. PLOS Computational Biology 15 e1007040. (https://doi.org/10.1371/ journal.pcbi.1007040)

Jaitin DA, Weiner A, Yofe I, Lara-Astiaso D, Keren-Shaul H, David E, Salame TM, Tanay A, Van Oudenaarden A \& Amit I 2016 Dissecting immune circuits by linking CRISPR-pooled screens with single-cell RNA-Seq. Cell 167 1883-1896.e15. (https://doi.org/10.1016/j. cell.2016.11.039)

Jennings RE, Berry AA, Strutt JP, Gerrard DT \& Hanley NA 2015 Human pancreas development. Development 142 3126-3137. (https://doi. org/10.1242/dev.120063)

Kalamakis G, Brune D, Ravichandran S, Bolz J, Fan W, Ziebell F, Stiehl T, Catala-Martinez F, Kupke J, Zhao S, et al. 2019 Quiescence modulates stem cell maintenance and regenerative capacity in the aging brain. Cell 176 1407-1419.e14. (https://doi.org/10.1016/j.cell.2019.01.040)

Kelberman D, Rizzoti K, Lovell-Badge R, Robinson IC \& Dattani MT 2009 Genetic regulation of pituitary gland development in human and mouse. Endocrine Reviews 30 790-829. (https://doi.org/10.1210/ er.2009-0008)

Kim DWW, Qianyi PW, Wang Z, Lin S, Sun C, Jiang L \& Blackshaw S 2019 Single cell RNA-Seq analysis identifies molecular mechanisms controlling hypothalamic patterning and differentiation. Biorxiv [epub]. (https://doi.org/10.1101/657148)

Krentz NAJ, Lee MYY, Xu EE, Sproul SLJ, Maslova A, Sasaki S \& Lynn FC 2018 Single-cell transcriptome profiling of mouse and hESC-derived pancreatic progenitors. Stem Cell Reports 11 1551-1564. (https://doi. org/10.1016/j.stemcr.2018.11.008)

La Manno G, Soldatov R, Zeisel A, Braun E, Hochgerner H, Petukhov V, Lidschreiber K, Kastriti M, Lonnerberg P, Furlan A, et al. 2018 RNA velocity of single cells. Nature $\mathbf{5 6 0}$ 494-498. (https://doi.org/10.1038/ s41586-018-0414-6)
Lambrechts D, Wauters E, Boeckx B, Aibar S, Nittner D, Burton O, Bassez A, Decaluwe H, Pircher A, van den Eynde K, et al. 2018 Phenotype molding of stromal cells in the lung tumor microenvironment. Nature Medicine 24 1277-1289. (https://doi. org/10.1038/s41591-018-0096-5)

Langlais D, Couture C, Kmita M \& Drouin J 2013 Adult pituitary cell maintenance: lineage-specific contribution of self-duplication. Molecular Endocrinology 27 1103-1112. (https://doi.org/10.1210/ me.2012-1407)

Larsen HL \& Grapin-Botton A 2017 The molecular and morphogenetic basis of pancreas organogenesis. Seminars in Cell and Developmental Biology 66 51-68. (https://doi.org/10.1016/j.semcdb.2017.01.005)

Le Tissier P, Campos P, Lafont C, Romano N, Hodson DJ \& Mollard P 2017 An updated view of hypothalamic-vascular-pituitary unit function and plasticity. Nature Reviews Endocrinology 13 257-267. (https://doi.org/10.1038/nrendo.2016.193)

Lee JH, Daugharthy ER, Scheiman J, Kalhor R, Ferrante TC, Terry R, Turczyk BM, Yang JL, Lee HS, Aach J, et al. 2015 Fluorescent in situ sequencing (FISSEQ) of RNA for gene expression profiling in intact cells and tissues. Nature Protocols 10 442-458. (https://doi. org/10.1038/nprot.2014.191)

Leng L, Sun J, Huang J, Gong F, Yang L, Zhang S, Yuan X, Fang F, Xu X, Luo Y, et al. 2019 Single-cell transcriptome analysis of uniparental embryos reveals parent-of-origin effects on human preimplantation development. Cell Stem Cell 25 697-712.e6. (https://doi. org/10.1016/j.stem.2019.09.004)

Leong DA, Lau SK, Sinha YN, Kaiser DL \& Thorner MO 1985 Enumeration of lactotropes and somatotropes among male and female pituitary cells in culture: evidence in favor of a mammosomatotrope subpopulation in the rat. Endocrinology 116 1371-1378. (https://doi.org/10.1210/endo-116-4-1371)

Li L, Dong J, Yan L, Yong J, Liu X, Hu Y, Fan X, Wu X, Guo H, Wang X, et al. 2017 Single-cell RNA-Seq analysis maps development of human germline cells and gonadal niche interactions. Cell Stem Cell 20 891-892. (https://doi.org/10.1016/j.stem.2017.05.009)

Liu Q, Li Y, Feng Y, Liu C, Ma J, Li Y, Xiang H, Ji Y, Cao Y, Tong X, et al. 2016 Single-cell analysis of differences in transcriptomic profiles of oocytes and cumulus cells at GV, MI, MII stages from PCOS patients. Science Reports 6 39638. (https://doi.org/10.1038/srep39638)

Llorens-Bobadilla E, Zhao S, Baser A, Saiz-Castro G, Zwadlo K \& MartinVillalba A 2015 Single-cell transcriptomics reveals a population of dormant neural stem cells that become activated upon brain injury. Cell Stem Cell 17 329-340. (https://doi.org/10.1016/j. stem.2015.07.002)

Lohr JG, Adalsteinsson VA, Cibulskis K, Choudhury AD, Rosenberg M, Cruz-Gordillo P, Francis JM, Zhang CZ, Shalek AK, Satija R, et al. 2014 Whole-exome sequencing of circulating tumor cells provides a window into metastatic prostate cancer. Nature Biotechnology 32 479-484. (https://doi.org/10.1038/nbt.2892)

Lovatt D, Ruble BK, Lee J, Dueck H, Kim TK, Fisher S, Francis C, Spaethling JM, Wolf JA, Grady MS, et al. 2014 Transcriptome in vivo analysis (TIVA) of spatially defined single cells in live tissue. Nature Methods 11 190-196. (https://doi.org/10.1038/nmeth.2804)

Macaulay IC, Haerty W, Kumar P, Li YI, Hu TX, Teng MJ, Goolam M, Saurat N, Coupland P, Shirley LM, et al. 2015 G\&T-seq: parallel sequencing of single-cell genomes and transcriptomes. Nature Methods 12 519-522. (https://doi.org/10.1038/nmeth.3370)

Macaulay IC, Ponting CP \& Voet T 2017 Single-cell multiomics: multiple measurements from single cells. Trends in Genetics 33 155-168. (https://doi.org/10.1016/j.tig.2016.12.003)

Mayran A, Sochodolsky K, Khetchoumian K, Harris J, Gauthier Y, Bemmo A, Balsalobre A \& Drouin J 2019 Pioneer and nonpioneer factor cooperation drives lineage specific chromatin opening. Nature Communications 10 3807. (https://doi.org/10.1038/s41467-01911791-9) 
Mays JC, Kelly MC, Coon SL, Holtzclaw L, Rath MF, Kelley MW \& Klein DC. 2018 Single-cell RNA sequencing of the mammalian pineal gland identifies two pinealocyte subtypes and cell typespecific daily patterns of gene expression. PLoS One 13 e0205883. (https://doi.org/10.1371/journal.pone.0205883)

Mickelsen LE, Bolisetty M, Chimileski BR, Fujita A, Beltrami EJ, Costanzo JT, Naparstek JR, Robson P \& Jackson AC 2019 Single-cell transcriptomic analysis of the lateral hypothalamic area reveals molecularly distinct populations of inhibitory and excitatory neurons. Nature Neuroscience 22 642-656. (https://doi.org/10.1038/ s41593-019-0349-8)

Mizrak D, Levitin HM, Delgado AC, Crotet V, Yuan J, Chaker Z, SilvaVargas V, Sims PA \& Doetsch F 2019 Single-cell analysis of regional differences in adult V-SVZ neural stem cell lineages. Cell Reports 26 394-406.e5. (https://doi.org/10.1016/j.celrep.2018.12.044)

Moffitt JR, Bambah-Mukku D, Eichhorn SW, Vaughn E, Shekhar K, Perez JD, Rubinstein ND, Hao J, Regev A, Dulac C, et al. 2018 Molecular, spatial, and functional single-cell profiling of the hypothalamic preoptic region. Science 362 eaau5324. (https://doi. org/10.1126/science.aau5324)

Molitch ME 2017 Diagnosis and treatment of pituitary adenomas: a review. JAMA 317 516-552. (https://doi.org/10.1001/ jama.2016.19699)

Mollard P, Hodson DJ, Lafont C, Rizzoti K \& Drouin J 2012 A tridimensional view of pituitary development and function. Trends in Endocrinoly and Metabolism 23 261-269. (https://doi.org/10.1016/j. tem.2012.02.004)

Mucenski ML, Mahoney R, Adam M, Potter AS \& Potter SS 2019 Single cell RNA-seq study of wild type and Hox9,10,11 mutant developing uterus. Science Reports 9 4557. (https://doi.org/10.1038/s41598-01940923-w)

Muller HL 2014 Craniopharyngioma. Endocrine Reviews 35 513-543. (https://doi.org/10.1210/er.2013-1115)

Muraro MJ, Dharmadhikari G, Grun D, Groen N, Dielen T, Jansen E, van Gurp L, Engelse MA, Carlotti F, de Koning EJ, et al. 2016 A single-cell transcriptome atlas of the human pancreas. Cell Systems 3 385-394 e3. (https://doi.org/10.1016/j.cels.2016.09.002)

Navin N, Kendall J, Troge J, Andrews P, Rodgers L, McIndoo J, Cook K, Stepansky A, Levy D, Esposito D, et al. 2011 Tumour evolution inferred by single-cell sequencing. Nature 472 90-94. (https://doi. org/10.1038/nature09807)

Ni X, Zhuo M, Su Z, Duan J, Gao Y, Wang Z, Zong C, Bai H, Chapman AR, Zhao J, et al. 2013 Reproducible copy number variation patterns among single circulating tumor cells of lung cancer patients. PNAS 110 21083-21088. (https://doi.org/10.1073/pnas.1320659110)

Ohyama K, Ellis P, Kimura S \& Placzek M 2005 Directed differentiation of neural cells to hypothalamic dopaminergic neurons. Development 132 5185-5197. (https://doi.org/10.1242/dev.02094)

Palii CG, Cheng Q, Gillespie MA, Shannon P, Mazurczyk M, Napolitani G, Price ND, Ranish JA, Morrissey E, Higgs DR, et al. 2019 Single-cell proteomics reveal that quantitative changes in co-expressed lineagespecific transcription factors determine cell fate. Cell Stem Cell 24 812820.e5. (https://doi.org/10.1016/j.stem.2019.02.006)

Patel AP, Tirosh I, Trombetta JJ, Shalek AK, Gillespie SM, Wakimoto H, Cahill DP, Nahed BV, Curry WT, Martuza RL, et al. 2014 Single-cell RNA-seq highlights intratumoral heterogeneity in primary glioblastoma. Science 344 1396-1401. (https://doi.org/10.1126/ science.1254257)

Pavlicev M, Wagner GP, Chavan AR, Owens K, Maziarz J, DunnFletcher C, Kallapur SG, Muglia L \& Jones H 2017 Single-cell transcriptomics of the human placenta: inferring the cell communication network of the maternal-fetal interface. Genome Research 27 349-361. (https://doi.org/10.1101/gr.207597.116)

Peng J, Sun BF, Chen CY, Zhou JY, Chen YS, Chen H, Liu L, Huang D, Jiang J, Cui GS, et al. 2019 Single-cell RNA-seq highlights intra- tumoral heterogeneity and malignant progression in pancreatic ductal adenocarcinoma. Cell Research 29 725-738. (https://doi. org/10.1038/s41422-019-0195-y)

Petersen MBK, Azad A, Ingvorsen C, Hess K, Hansson M, GrapinBotton A \& Honore C 2017 Single-cell gene expression analysis of a human ESC model of pancreatic endocrine development reveals different paths to beta-cell differentiation. Stem Cell Reports 9 1246-1261. (https://doi.org/10.1016/j.stemcr.2017.08.009)

Pijuan-Sala B, Griffiths JA, Guibentif C, Hiscock TW, Jawaid W, CaleroNieto FJ, Mulas C, Ibarra-Soria X, Tyser RCV, Ho DLL, et al. 2019 A single-cell molecular map of mouse gastrulation and early organogenesis. Nature 566 490-495. (https://doi.org/10.1038/s41586019-0933-9)

Prince KL, Walvoord EC \& Rhodes SJ 2011 The role of homeodomain transcription factors in heritable pituitary disease. Nature Reviews Endocrinology 7 727-737. (https://doi.org/10.1038/nrendo.2011.119)

Qiu WL, Zhang YW, Feng Y, Li LC, Yang L \& Xu CR 2017 Deciphering pancreatic islet beta cell and alpha cell maturation pathways and characteristic features at the single-cell level. Cell Metabolism 25 1194-1205.e4. (https://doi.org/10.1016/j.cmet.2017.04.003)

Ramond C, Beydag-Tasoz BS, Azad A, van de Bunt M, Petersen MBK, Beer NL, Glaser N, Berthault C, Gloyn AL, Hansson M, et al. 2018 Understanding human fetal pancreas development using subpopulation sorting, RNA sequencing and single-cell profiling. Development 145 dev165480. (https://doi.org/10.1242/dev.165480)

Regev A, Teichmann SA, Lander ES, Amit I, Benoist C, Birney E, Bodenmiller B, Campbell P, Carninci P, Clatworthy M, et al. 2017 The human cell atlas. eLife 6 e27041. (https://doi.org/10.7554/ elife.27041)

Rizzoti K, Akiyama H \& Lovell-Badge R 2013 Mobilized adult pituitary stem cells contribute to endocrine regeneration in response to physiological demand. Cell Stem Cell 13 419-432. (https://doi. org/10.1016/j.stem.2013.07.006)

Robins SC, Stewart I, Mcnay DE, Taylor V, Giachino C, Goetz M, Ninkovic J, Briancon N, Maratos-Flier E, Flier JS, et al. 2013 alphaTanycytes of the adult hypothalamic third ventricle include distinct populations of FGF-responsive neural progenitors. Nature Communications 4 2049. (https://doi.org/10.1038/ncomms3049)

Romanov RA, Zeisel A, Bakker J, Girach F, Hellysaz A, Tomer R, Alpar A, Mulder J, Clotman F, Keimpema E, et al. 2017 Molecular interrogation of hypothalamic organization reveals distinct dopamine neuronal subtypes. Nature Neuroscience 20 176-188. (https://doi.org/10.1038/nn.4462)

Ruf-Zamojski F, Fribourg M, Ge Y, Nair V, Pincas H, Zaslavsky E, Nudelman G, Tuminello SJ, Watanabe H, Turgeon JL, et al. 2018a Regulatory architecture of the LbetaT2 gonadotrope cell underlying the response to gonadotropin-releasing hormone. Frontiers in Endocrinology 9 34. (https://doi.org/10.3389/fendo.2018.00034)

Ruf-Zamojski F, Ge Y, Nair V, Zamojski M, Pincas H, Toufaily C, TomeGarcia J, Stoeckius M, Stephenson W, Smith GR, et al. 2018b. Singlecell stabilization method identifies gonadotrope transcriptional dynamics and pituitary cell type heterogeneity. Nucleic Acids Research 46 11370-11380. (https://doi.org/10.1093/nar/gky991)

Saatcioglu HD, Kano M, Horn H, Zhang L, Samore W, Nagykery N, Meinsohn MC, Hyun M, Suliman R, Poulo J, et al. 2019 Single-cell sequencing of neonatal uterus reveals an Misr2+ endometrial progenitor indispensable for fertility. eLife 8 e46349. (https://doi. org/10.7554/elife.46349)

Scully KM, Skowronska-Krawczyk D, Krawczyk M, Merkurjev D, Taylor H, Livolsi A, Tollkuhn J, Stan RV \& Rosenfeld MG 2016 Epithelial cell integrin beta1 is required for developmental angiogenesis in the pituitary gland. PNAS 113 13408-13413. (https://doi.org/10.1073/pnas.1614970113)

Segerstolpe A, Palasantza A, Eliasson P, Andersson EM, Andreasson AC, Sun X, Picelli S, Sabirsh A, Clausen M, Bjursell MK, et al. 2016 (c) 2020 Society for Endocrinology Published by Bioscientifica Ltd. Printed in Great Britain 
Single-cell transcriptome profiling of human pancreatic islets in health and type 2 diabetes. Cell Metabolism 24 593-607. (https://doi. org/10.1016/j.cmet.2016.08.020)

Senovilla L, Núñez L, de Campos JM, de Luis DA, Romero E, GarciaSancho J \& Villalobos C 2015 Single-cell phenotypic characterization of human pituitary GHomas and non-functioning adenomas based on hormone content and calcium responses to hypothalamic releasing hormones. Frontiers Oncology 5 124. (https://doi. org/10.3389/fonc.2015.00124)

Shin J, Berg DA, Zhu Y, Shin JY, Song J, Bonaguidi MA, Enikolopov G, Nauen DW, Christian KM, Ming GL, et al. 2015 Single-cell RNA-Seq with waterfall reveals molecular cascades underlying adult neurogenesis. Cell Stem Cell 17 360-372. (https://doi.org/10.1016/j. stem.2015.07.013)

Somigliana E, Paffoni A, Busnelli A, Filippi F, Pagliardini L, Vigano P \& Vercellini P 2016 Age-related infertility and unexplained infertility: an intricate clinical dilemma. Human Reproduction 31 1390-1396. (https://doi.org/10.1093/humrep/dew066)

Stevant I \& Nef S 2018 Single cell transcriptome sequencing: A new approach for the study of mammalian sex determination. Molecular Cell Endocrinology 468 11-18. (https://doi.org/10.1016/j. mce.2018.01.013)

Stevant I, Neirijnck Y, Borel C, Escoffier J, Smith LB, Antonarakis SE, Dermitzakis ET \& Nef S 2018 Deciphering cell lineage specification during male sex determination with single-cell RNA sequencing. Cell Reports 22 1589-1599. (https://doi.org/10.1016/j.celrep.2018.01.043)

Stuart T, Butler A, Hoffman P, Hafemeister C, Papalexi E, Mauck WM, 3rd, Hao Y, Stoeckius M, Smibert P \& Satija R 2019 Comprehensive integration of single-cell data. Cell 177 1888-1902.e21. (https://doi. org/10.1016/j.cell.2019.05.031)

Svensson V, Vento-Tormo R \& Teichmann SA 2018 Exponential scaling of single-cell RNA-seq in the past decade. Nature Protocols $\mathbf{1 3}$ 599-604. (https://doi.org/10.1038/nprot.2017.149)

Tang F, Barbacioru C, Nordman E, Li B, Xu N, Bashkirov VI, Lao K \& Surani MA 2010 RNA-Seq analysis to capture the transcriptome landscape of a single cell. Nature Protocols 5 516-535. (https://doi. org/10.1038/nprot.2009.236)

Todorov H \& Saeys Y 2019 Computational approaches for highthroughput single-cell data analysis. FEBS Journal 286 1451-1467. (https://doi.org/10.1111/febs.14613)

Trapnell C 2015 Defining cell types and states with single-cell genomics. Genome Research 25 1491-1498. (https://doi.org/10.1101/ gr.190595.115)

Trapnell C, Cacchiarelli D, Grimsby J, Pokharel P, Li S, Morse M, Lennon NJ, Livak KJ, Mikkelsen TS \& Rinn JL 2014 The dynamics and regulators of cell fate decisions are revealed by pseudotemporal ordering of single cells. Nature Biotechnology 32 381-386. (https://doi. org/10.1038/nbt.2859)

Tritschler S, Theis FJ, Lickert H \& Bottcher A 2017 Systematic single-cell analysis provides new insights into heterogeneity and plasticity of the pancreas. Molecular Metabolism 6 974-990. (https://doi. org/10.1016/j.molmet.2017.06.021)

Tsang JCH, Vong JSL, Ji L, Poon LCY, Jiang P, Lui KO, Ni YB, To KF, Cheng YKY, Chiu RWK, et al. 2017 Integrative single-cell and cellfree plasma RNA transcriptomics elucidates placental cellular dynamics. PNAS 114 E7786-E7795. (https://doi.org/10.1073/ pnas.1710470114)

van Gurp L, Muraro MJ, Dielen T, Seneby L, Dharmadhikari G, Gradwohl G, van Oudenaarden A \& de Koning EJP 2019 A transcriptomic roadmap to alpha- and beta-cell differentiation in the embryonic pancreas. Development 146 e46349. (https://doi. org/10.7554/elife.46349)

van Velthoven CTJ \& Rando TA 2019 Stem cell quiescence: Dynamism, restraint, and cellular idling. Cell Stem Cell 24 213-225. (https://doi. org/10.1016/j.stem.2019.01.001)

Vento-Tormo R, Efremova M, Botting RA, Turco MY, Vento-Tormo M, Meyer KB, Park JE, Stephenson E, Polanski K, Goncalves A, et al. 2018 Single-cell reconstruction of the early maternal-fetal interface in humans. Nature 563 347-353. (https://doi.org/10.1038/s41586018-0698-6)

Veres A, Faust AL, Bushnell HL, Engquist EN, Kenty JH, Harb G, Poh YC, Sintov E, Gurtler M, Pagliuca FW, et al. 2019 Charting cellular identity during human in vitro beta-cell differentiation. Nature $\mathbf{5 6 9}$ 368-373. (https://doi.org/10.1038/s41586-019-1168-5)

Vertesy A, Arindrarto W, Roost MS, Reinius B, Torrens-Juaneda V, Bialecka M, Moustakas I, Ariyurek Y, Kuijk E, Mei H, et al. 2018 Parental haplotype-specific single-cell transcriptomics reveal incomplete epigenetic reprogramming in human female germ cells. Nature Communications 9 1873. (https://doi.org/10.1038/s41467-018-04215-7)

Villani AC, Satija R, Reynolds G, Sarkizova S, Shekhar K, Fletcher J, Griesbeck M, Butler A, Zheng S, Lazo S, et al. 2017 Single-cell RNAseq reveals new types of human blood dendritic cells, monocytes, and progenitors. Science 356 eaah4573. (https://doi.org/10.1126/ science.aah4573)

Villani V, Thornton ME, Zook HN, Crook CJ, Grubbs BH, Orlando G, De Filippo R, Ku HT \& Perin L 2019 SOX9+/PTF1A+ cells define the tip progenitor cells of the human fetal pancreas of the second trimester. Stem Cells Translational Medicine 20198 1249-1264. (https://doi. org/10.1002/sctm.19-0231)

Vuong NH, Cook DP, Forrest LA, Carter LE, Robineau-Charette P, Kofsky JM, Hodgkinson KM \& Vanderhyden BC 2018 Single-cell RNA-sequencing reveals transcriptional dynamics of estrogeninduced dysplasia in the ovarian surface epithelium. PLoS Genetics 14 e1007788. (https://doi.org/10.1371/journal.pgen.1007788)

Wagner DE, Weinreb C, Collins ZM, Briggs JA, Megason SG \& Klein AM 2018 Single-cell mapping of gene expression landscapes and lineage in the zebrafish embryo. Science 360 981-987. (https://doi. org/10.1126/science.aar4362)

Wang M, Liu X, Chang G, Chen Y, An G, Yan L, Gao S, Xu Y, Cui Y, Dong J, et al. 2018 Single-cell RNA sequencing analysis reveals sequential cell fate transition during human spermatogenesis. Cell Stem Cell 23 599-614.e4. (https://doi.org/10.1016/j.stem.2018.08.007)

Wang Y, Waters J, Leung ML, Unruh A, Roh W, Shi X, Chen K, Scheet P, Vattathil S, Liang H, et al. 2014 Clonal evolution in breast cancer revealed by single nucleus genome sequencing. Nature 512 155-160. (https://doi.org/10.1038/nature13600)

Wang YJ, Schug J, Won KJ, Liu C, Naji A, Avrahami D, Golson ML \& Kaestner KH 2016 Single-cell transcriptomics of the human endocrine pancreas. Diabetes 65 3028-3038. (https://doi.org/10.2337/ db16-0405)

Wollny D, Zhao S, Everlien I, Lun X, Brunken J, Brune D, Ziebell F, Tabansky I, Weichert W, Marciniak-Czochra A, et al. 2016 Single-cell analysis uncovers clonal acinar cell heterogeneity in the adult pancreas. Developmental Cell 39 289-301. (https://doi.org/10.1016/j. devcel.2016.10.002)

Xie Y \& Dorsky RI 2017 Development of the hypothalamus: conservation, modification and innovation. Development 144 1588-1599. (https://doi.org/10.1242/dev.139055) (c) 2020 Society for Endocrinology Published by Bioscientifica Ltd. Printed in Great Britain 
Xin Y, Kim J, Okamoto H, Ni M, Wei Y, Adler C, Murphy AJ, Yancopoulos GD, Lin C \& Gromada J 2016 RNA Sequencing of single human islet cells reveals type 2 diabetes genes. Cell Metabolism 24 608-615. (https://doi.org/10.1016/j.cmet.2016.08.018)

Xue Z, Huang K, Cai C, Cai L, Jiang CY, Feng Y, Liu Z, Zeng Q, Cheng L, Sun YE, et al. 2013 Genetic programs in human and mouse early embryos revealed by single-cell RNA sequencing. Nature $\mathbf{5 0 0}$ 593-597. (https://doi.org/10.1038/nature12364)

Yan L, Yang M, Guo H, Yang L, Wu J, Li R, Liu P, Lian Y, Zheng X, Yan J, et al. 2013 Single-cell RNA-Seq profiling of human preimplantation embryos and embryonic stem cells. Structural and Molecular Biology 20 1131-1139. (https://doi.org/10.1038/nsmb.2660)

Zeng C, Mulas F, Sui Y, Guan T, Miller N, Tan Y, Liu F, Jin W, Carrano AC, Huising MO, et al. 2017 Pseudotemporal ordering of single cells reveals metabolic control of postnatal beta cell proliferation. Cell Metabolism 25 1160-1175.e11. (https://doi.org/10.1016/j.cmet.2017.04.014)
Zhang Y, Yan Z, Qin Q, Nisenblat V, Chang HM, Yu Y, Wang T, Lu C, Yang M, Yang S, et al. 2018 Transcriptome landscape of human folliculogenesis reveals oocyte and granulosa cell interactions. Molecular Cell 72 1021-1034.e4. (https://doi.org/10.1016/j. molcel.2018.10.029)

Zhou Q \& Melton DA 2018 Pancreas regeneration. Nature 557 351-358. (https://doi.org/10.1038/s41586-018-0088-0)

Zhou Q, Wang M, Yuan Y, Wang X, Fu R, Wan H, Xie M, Liu M, Guo X, Zheng $\mathrm{Y}$, et al. 2016 Complete meiosis from embryonic stem cellderived germ cells in vitro. Cell Stem Cell 18 330-340. (https://doi. org/10.1016/j.stem.2016.01.017)

Ziegenhain C, Vieth B, Parekh S, Reinius B, Guillaumet-Adkins A, Smets M, Leonhardt H, Heyn H, Hellmann I \& Enard W 2017 Comparative analysis of single-cell RNA sequencing methods. Molecular Cell 65 631-643.e4. (https://doi.org/10.1016/j. molcel.2017.01.023)

Received in final form 29 April 2020

Accepted 2 June 2020

Accepted Manuscript published online 2 June 2020
(C) 2020 Society for Endocrinology Published by Bioscientifica Ltd. Printed in Great Britain 